\begin{tabular}{|c|c|c|}
\hline & $\begin{array}{l}\text { Jurnal Teknologi Kimia Unimal } \\
\text { http://ojs.unimal.ac.id/index.php/jtk }\end{array}$ & $\begin{array}{l}\text { Jurnal } \\
\text { Teknologi } \\
\text { Kimia } \\
\text { Unimal }\end{array}$ \\
\hline
\end{tabular}

\title{
OPTIMASI PROSES PEMBUATAN BIODIESEL DARI MINYAK BIJI JARAK KEPYAR (Ricinus communis L.) DENGAN METODE EKSTRAKSI REAKTIF
}

\author{
Wawan Setiawan ${ }^{1}$, Azhari $^{1}$, Novi Slyvia ${ }^{1}$ \\ ${ }^{1}$ Jurusan Teknik Kimia, Fakultas Teknik, Universitas Malikussaleh \\ Kampus Bukit Indah Kec. Muara Satu, Aceh Utara - Fax (0645) 44450 \\ Korespondensi: HP: 082361424626, e-mail: wawansetiawan280@yahoo.co.id
}

\begin{abstract}
Abstrak
Biodiesel merupakan suatu bahan bakar alternatif yang ramah lingkungan.Dalam penelitian ini bahan baku yang digunakan dalam pembuatan biodiesel adalah minyak Jarak kepyar (Ricinus communis L). Proses pembuatan biodiesel yang digunakan adalah reaksi eksraksi reaktif, yaitu salah satu proses pembuatan biodiesel dari minyak jarak kepyar dengan menggunakan pelarut etanol. Adapun tujuan dari penelitian ini adalah untuk mencari kondisi optimum proses pembuatan biodiesel dari minyak jarak kepyar dengan menggunakan software design expert 6.0.8 dengan metode response surface methogology (RSM) model central composite design (CCD). Minyak jarak kepyar di esterifikasi terlebih dulu. Adapun perbandingan mol yang digunakan (minyak : alkohol = 1:5,1:5.5,1:6), persen katalis $=0,95 \%$ dengan suhu reaksi $60^{\circ}, 65^{\circ}$ dan $70^{\circ} \mathrm{C}$.

Suhu optimum pada percobaan ini yaitu $65^{\circ} \mathrm{C}$ dengan waktu reaksi 150 menit mendapatkan yield sebesar 28.55\%. Biodiesel yang dihasilkan dianalisa sifat fisika dan kimia seperti densitas, flashpoint, dan yield.
\end{abstract}

Kata kunci: biodiesel, minyak jarak kepyar, esterefikasi, optimum response surface methodology

\section{Pendahuluan}

Biodiesel adalah bahan bakar minyak (BBM) yang dibuat dari bahan nabati berupa lemak atau minyak untuk digunakan pada mesin diesel. Biodiesel termasuk bahan energi yang dapat dipulihkan, karena dapat ditanam pada areal kehutanan, pertanian, lahan rakyat dan lain-lain (Pakpahan, 2001).

Penggunaan biodiesel sebagai sumber energi alternatif memiliki banyak keunggulan komparatif antara lain: ketersediaan sumber daya, ketersediaan teknologi, keunggulan kualitas produk, memberikan dampak positif terhadap 
ekonomi makro (devisa negara) dan ekonomi mikro seperti penciptaan lapangan kerja baru dan peningkatan pendapatan masyarakat sekitar lokasi bahan baku. Beberapa keunggulan kualitas biodiesel dibanding petrodiesel (solar) adalah: resiko terbakar lebih rendah, kualitas pembakaran seimbang, emisi gas toksid lebih rendah sampai nol, lebih mudah terurai scara biologis, pengadaannya banyak melibatkan masyarakat dari kelompok kurang mampu serta memberikan dampak positif pada konservasi tanah dan air (Sudradjat dkk., 2003).

Tanaman jarak kepyar merupakan tanaman tahunan yang tahan kekeringan. Tanaman ini juga mampu tumbuh dengan cepat dan kuat di lahan yang beriklim panas, tandus, dan berbatu. Wilayah yang cocok sebagai tumbuhnya adalah di dataran rendah hingga ketinggian 3000 mdpl. Tanaman ini dapat memberikan nilai ekonomis karena bijinya menghasilkan minyak sebagai bahan baku pembuatan biodiesel (Heyne, 1987). Penelitian tentang bahan bakar alternatif biodiesel telah banyak dilakukan dengan memakai berbagai macam minyak nabati. Misal Amerika Serikat, menggunakan minyak kedelai sebagai bahan baku, di Eropa menggunakan rapeseed oil, dan di negara- negara tropis menggunakan minyak kelapa dan minyak sawit (Knothe et al., 1997). Jarak kepyar (R. communis) banyak digunakan pada industri kimia seperti pabrik cat, vernis, pelumas, tinta cetak, pabrik kosmetik, parfum, farmasi, bubur kertas, serta sebagai bahan baku industri nilon dan plastik (Osava, 2001).

Berdasarkan penelitian yang sudah dilakukan dengan metode microwave di mana kondisi optimum pada rasio 1:6 dan menghasilkan yield sebesar 92,67\% dengan waktu 10 menit. Densitas biodiesel yang dihasilkan sebesar 0,94 g/ml (Dewi, 2015).

Minyak jarak kepyar (ricinus communis) berwarna kuning pucat, tetapi setelah dilakukan proses refining dan bleaching warna tersebut hilang sehingga menjadi hampir tidak berwarna. Minyak jarak kepyar (Ricinus communis) ini tidak mudah tengik. Minyak jarak kepyar (Ricinus communis) larut dalam alkohol, eter, klorofom, dan asam asetat glasial. Minyak jarak kepyar (Ricinus communis) tidak larut dalam minyak mineral. Minyak jarak kepyar (Ricinus communis) hampir keseluruhan berada dalam bentuk trigliserida, terutama resinolenin dengan 
asam risinoleat sebagai komponen asam lemaknya (Weiss, 1983). Biji jarak kepyar terdiri dari $75 \%$ kernel ( daging biji ) dan $25 \%$ kulit dengan komposisi sebagai berikut: adapun komposisi biji jarak kepyar dapat dilihat pada Tabel 1.

Tabel 1 Komposisi biji jarak kepyar

\begin{tabular}{|c|c|}
\hline Komponen & Jumlah (\%) \\
\hline Minyak & 54 \\
\hline Karbohidrat & 13 \\
\hline Serat & 12.5 \\
\hline Abu & 2.5 \\
\hline Protein & 18 \\
\hline
\end{tabular}

(Sumber : Ketaren, 1986).

Adapun kandungan asam lemak dari jarak kepyar dapat dilihat pada Tabel 2.

Tabel 2 Kandungan asam lemak jarak kepyar

\begin{tabular}{|l|c|}
\hline Komponen & Jumlah (\%) \\
\hline Asam risiloneat & 85 \\
\hline Asam oleat & 8.5 \\
\hline Asam linoleat & 3.5 \\
\hline Asam stearat & $0.5-2.0$ \\
\hline Asam dihidroksi stearat & $1-2$ \\
\hline
\end{tabular}

Reaksi transesterifikasi disebut juga dengan reaksi alkoholisis. Alkohol yang biasa digunakan dalam rekasi tranesterifikasi adalah metanol. Proses transestrifikasi dengan menggunakan katalis basa mampu mencapai $98 \%$ konversi dengan waktu reaksi minimum. Berikut ini adalah tahap-tahap reaksi transesterifikasi yang dapat dilihat pada Gambar 1 dan 2.

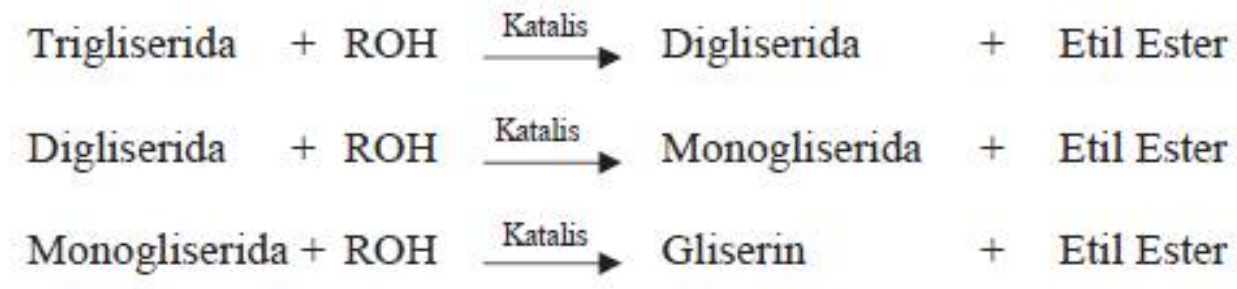

Gambar 1 Tahapan reaksi transesterifikasi (Syam, 2012) 


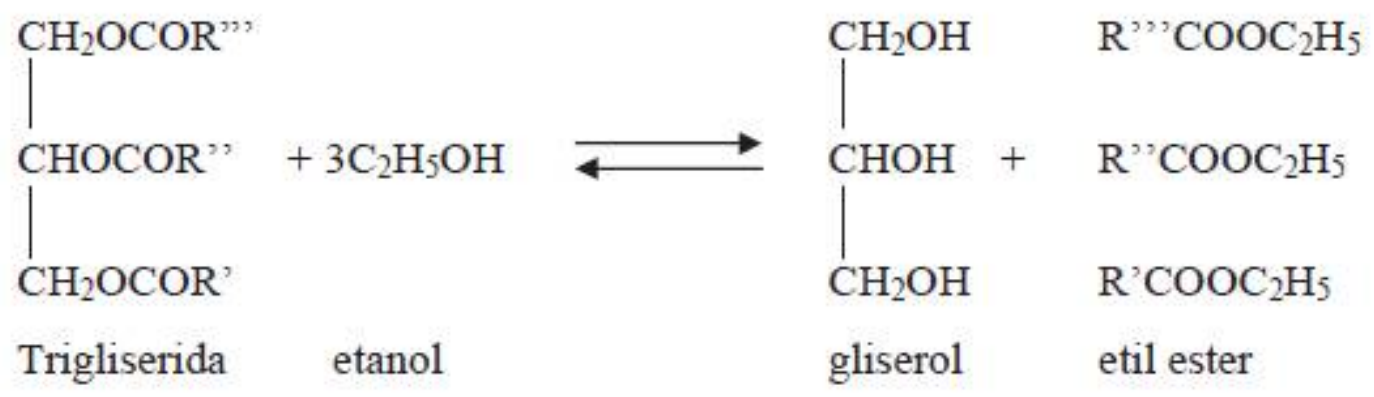

Gambar 2 Reaksi pembentukan metil ester

Ekstraksi reaktif adalah proses yang melibatkan reaksi dan pemisahan dilakukan secara bersamaan. Pemisahan fase dapat dilakukan secara alami dalam sestem reaktif dengan menambahkan pelarut. Di dalam ekstraksi reaktif, alkohol bertindak sebagai pelarut diproses ekstraksi dan sebagai reagent pada reaksi transesterifikasi selama ekstraksi reaktif berlangsung. Oleh sebab itu alkohol diperlukan dalam jumlah yang sangat banyak (Jairurob, 2013).

\section{Metode Penelitian}

\subsection{Bahan dan Peralatan}

Adapaun bahan yang digunakan dalam penelitian ini adalah biji jarak kepyar, $\mathrm{KOH}$, etanol, hexane dan aquadest. Alat yang digunakan dalam penelitian ini adalah erlenmeyer, beakerglass, destilasi, labu leher tiga, magnetic stirrer, corong pemisah, kondenser dan hot plate.

\subsection{Prosedur Kerja}

Penelitian dilakukan melalui dua tahap yaitu tahap persiapan bahan, tahap kedua adalah analisis hasil. Diambil biji buah jarak kepyar sudah tua kemudian dibersihkan dan dikeringkan selanjutnya dihancurkan dengan ukuran $\pm 1 \mathrm{~mm}$. Kemudian biji dengan berat 200 gram yang telah dihaluskan dan dikeringkan tadi, dimasukan ke dalam labu leher tiga. Selanjutnya dimasukan $300 \mathrm{ml}$ pelarut nhexane dan sejumlah etanol yang telah dilarutkan dengan $\mathrm{KOH}$ dengan kadar katalis $0,95 \%$ ke dalam labu leher tiga. Kemudian campuran dipanasan dengan suhu 60, 65 dan $70^{\circ} \mathrm{C}$ selama waktu 100, 150 dan 200 menit dengan kecepatan pengaduk $400 \mathrm{rpm}$. 


\section{Hasil dan Diskusi}

Menurut Montgomery (Hidayat, 2012) Response Surface Methodology (RSM) merupakan suatu metode gabungan antara teknik matematika dan teknik statistika, digunakan untuk membuat model dan menganalisa suatu respon y yang dipengaruhi oleh beberapa variabel bebas (factor $x$ ) guna mengoptimalkan respon tersebut. Hubungan antara respon $y$ dan variabel bebas $x$ adalah sebagai berikut:

$y=f(x 1, x 2, \ldots ., x k)+\varepsilon$

Dimana :

$\mathrm{y}=$ variabel respon

$\mathrm{x} 1, \mathrm{x} 2, \ldots \ldots \mathrm{xk}=$ variabel bebas/faktor

$\varepsilon=$ error

Dikarenakan bentuk fungsi respon f yang sebenarnya tidak diketahui, maka harus ada pendekatannya. Perkiraan model didasarkan pada observasi dari proses atau sistem sehingga dapat membentuk model empirisnya. Jika respon yang diharapkan diasumsikan sebagai $\mathrm{E}(\mathrm{y})=\mathrm{f}(\mathrm{x} 1, \mathrm{x} 2, \ldots ., \mathrm{xk})=\eta$, maka permukaannya dilukiskan oleh $\eta=f(x 1, x 2, \ldots ., x k)$ yang disebut permukaan respon. Umumnya response surface ditampilkan secara grafik dan untuk membantu visualisasi dari bentuk permukaan plot sering digunakan countur dari permukaan respon. Garis countur yang terbentuk mempresentasi ketinggian permukaan yang terbentuk.

Langkah pertama yang dilakukan adalah mencari bentuk hubungan antara respon dengan perlakuannya. Bentuk hubungan linier merupakan bentuk hubungan yang pertama kali dicobakan untuk menggambarkan hubungan tersebut. Jika ternyata bentuk hubungan antara respon dengan perlakuan adalah linier maka pendekatan fungsinya disebut first-order model (mode pertama), seperti yang ditunjukkan dalam persamaan 2:

$$
\left.\mathrm{Y}=\mathrm{p}^{0}+\right)_{i=1}^{K} \beta
$$

Jika bentuk hubangannya merupakan kuadrat maka pendekatan fungsinya disebut second-order model

$$
\left.\mathrm{Y}={ }_{i=1}^{k} \beta \quad+{ }_{l=1}^{k} \beta \quad 2+\right) \operatorname{pij} \mathrm{XiXj}+\mathrm{s}
$$




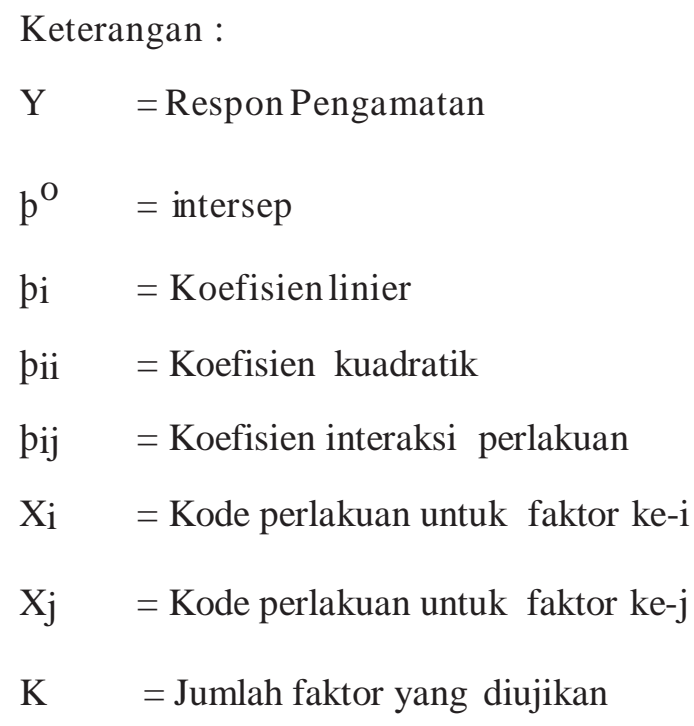

Kemudian dari model orde kedua ditentukan titik stasioner, karakteristik permukaan respon dan model optimasinya. RSM pada prinsipnya adalah teknik yang meliputi analisis regresi dan desain eksperimen untuk menyelesaikan masalah optimasi (Hidayat, 2012).

Menurut Sudjana (Hidayat, 2012) di dalam RSM, dibutuhkan pencarian titik optimum yang berulang-ulang pada desain yang digunakan untuk perpindahan dari eksperimen orde pertama menuju eksperimen orde kedua.

Pencarian tersebut dilakukan jika pada eksperimen orde pertama terdapat efek lengkungan, selanjutnya eksperimen orde pertama digantikan oleh eksperimen orde kedua. Desain faktorial $2^{\mathrm{k}}$ dan desain fraksional faktorial $2^{\mathrm{k}-\mathrm{p}}$ adalah desain yang sesuai untuk mengestimasi model orde pertama. Uji kelengkungan eksperimen orde pertama dilakukan dengan metode penambahan titik pusat dengan ukuran $\mathrm{nf}$ dan $\mathrm{nc}$ dimana " $\mathrm{f}$ " menandakan desain faktorial dan "c" menandakan titik pusat.

Pada desain faktorial diberi kode '-' untuk level rendah dan '+' untuk level tinggi, sedangkan titik pusat diberi kode ' 0 '. Misalkan yf adalah rata-rata sampel faktorial dan yc adalah rata-rata sampel pada titik pusat. Selisih dari yf - yc dapat digunakan untuk menguji adanya lengkungan kuadrat. Apabila nilai yf - yc kecil, maka titik pusat berada atau dekat pada bidang yang dilewati titik faktorial, dan 
pada bagian tersebut tidak terdapat lengkungan kuadrat. Sebaliknya jika yf - yc besar, maka disana terdapat lengkungan kuadrat.

\subsection{Interaksi antara suhu dan waktu}

Grafik tiga dimensi yang menunjukkan interaksi antara suhu dan waktu dapat dilihat pada Gambar 3.

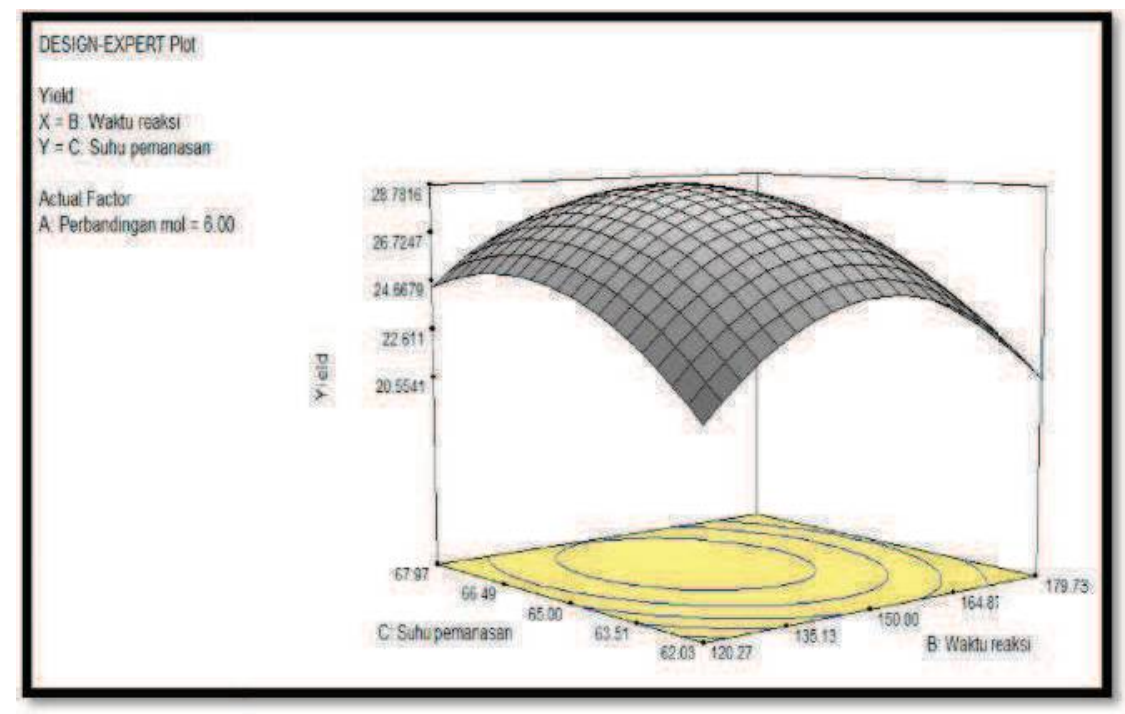

Gambar 3 Interaksi antara suhu dan waktu

Gambar 3 menunjukkan interaksi antara suhu dan waktu, dimana titik maksimum yang diperoleh yaitu $65^{\circ} \mathrm{C}$ dan lamanya berlangsung reaksi selama 150 menit dengan jumlah konversi yield sebanyak $28.51 \%$, sedangkan titik minimum terletak pada suhu $62^{\circ} \mathrm{C}$ dan lamanya reaksi 120 menit dengan konversi $16.55 \%$.

Suhu reaksi mempengaruhi kecepatan reaksi transesterifikasi dalam pembentukan biodiesel. Pada umumnya reaksi transesterifikasi dilakukan pada suhu $60-65{ }^{\circ} \mathrm{C}$ pada tekanan atmosfer. Kecepatan reaksi akan meningkat sejalan dengan kenaikan temperatur, yang berarti semakin banyak energi yang dapat digunakan reaksi untuk mencapai energi aktivasi, sehingga akan menyebabkan semakin banyak tumbukan terjadi antara molekul-molekul reaktan. 


\subsection{Interaksi antara perbandingan mol dan suhu}

Gambar 4 menunjukkan interaksi antara perbandingan mol dan suhu.

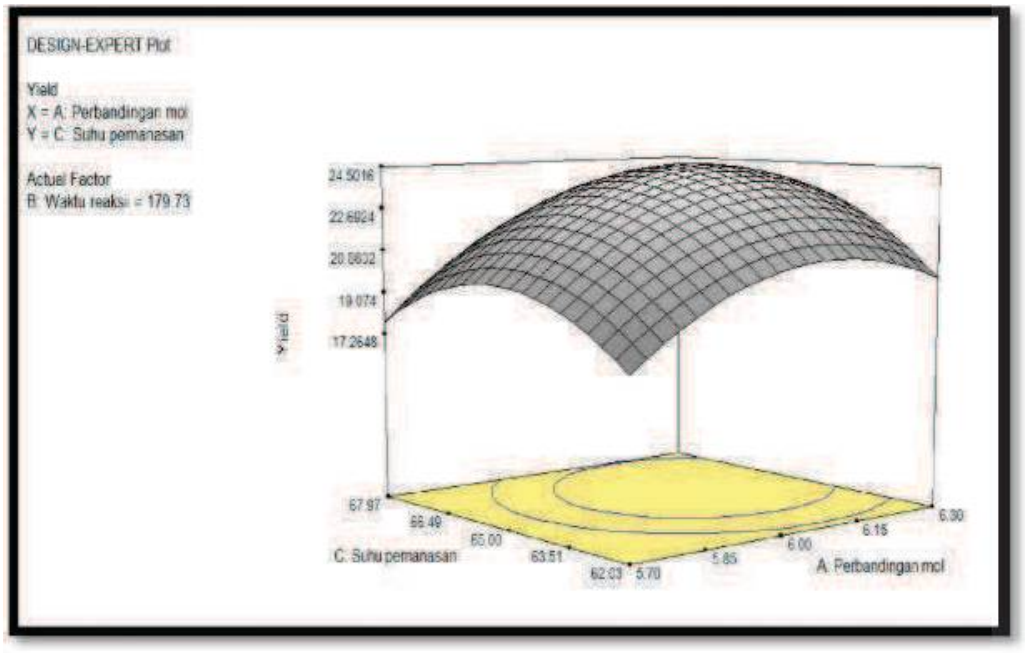

Gambar 4 Interaksi antara perbandingan mol dan suhu

Titik maksimum yang diperoleh berada pada perbandingan mol reaktan 1:6 dan suhu $65^{\circ} \mathrm{C}$ dengan jumlah konversi yield sebanyak $28.51 \%$, sedangkan titik minimum terletak pada kondisi perbandingan mol 1:5.7 pada suhu $62{ }^{\circ} \mathrm{C}$ dengan konversi yield sebanyak 16.55\%. Dengan demikian, suhu yang paling berpengaruh pada ekstraksi reaktif dengan menggunakan katalis $\mathrm{KOH}$ yaitu pada suhu $65^{\circ} \mathrm{C}$. Pada reaksi transesetrifikasi, penggunaan suhu yang tidak tepat dapat mengakibatkan reaksi tidak sempurna dan menyebabkan berkurangnya konversi yield biodiesel. Penggunaan suhu yang tepat mengakibatkan reaksi bergeser ke arah kanan (produk), peningkatan laju reaksi ini disebabkan oleh meningkatnya konstanta laju reaksi yang merupakan fungsi dari temperatur. Reaksi transesterefikasi merupakan reaksi reversible, maka pada kondisi suhu yang tinggi kesetimbangan bergeser ke arah kiri (dekomposisi produk). 


\subsection{Interaksi antara waktu dan perbandingan mol}

Grafik tiga dimensi yang menunjukkan interaksi antara waktu dan perbandingan mol dapat dilihat dalam Gambar 5.

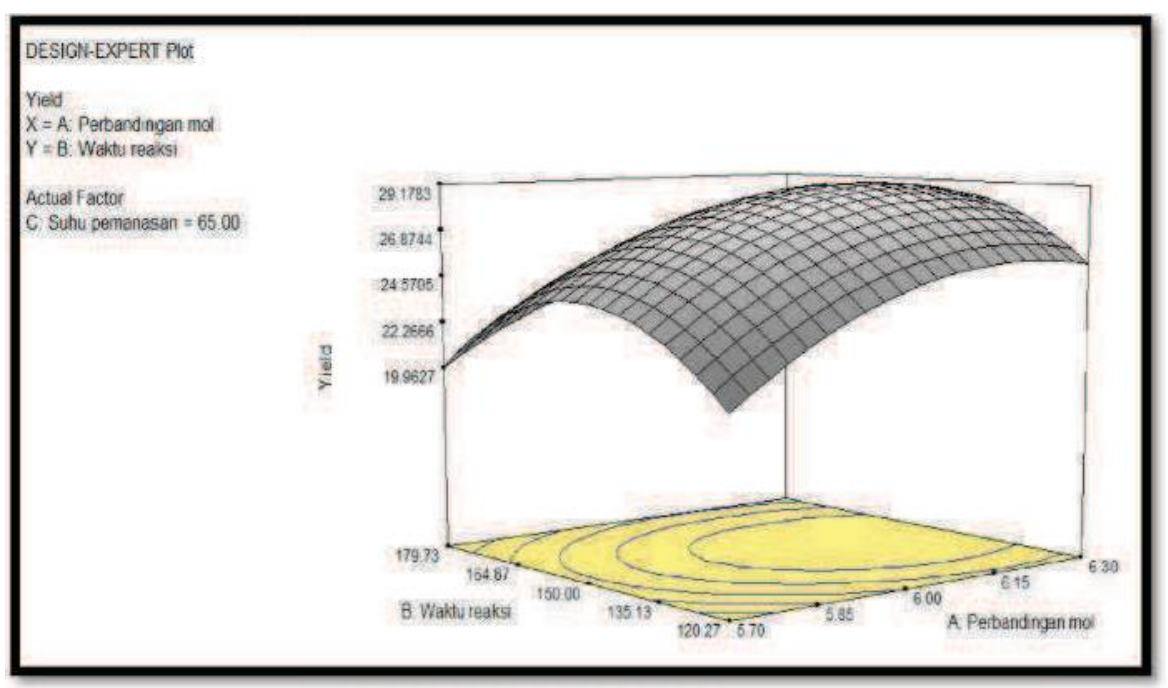

Gambar 5 Interaksi antara waktu dan perbandingan mol

Gambar 5 menunjukkan interaksi antara perbandingan mol dan suhu, di mana titik maksimum yang diperoleh berada pada perbandingan mol reaktan 1:6 berlagsung selama 150 menit, dengan jumlah konversi yield sebanyak 28.51\%. sedangkan titik minimum terletak pada kondisi perbandingan mol 1:5.7 dengan lama waktu reaksi yaitu 120 menit, yield yang diperoleh sebanyak $16.55 \%$.

\section{Simpulan}

Dari perhitungan berdasarkan model yang diperoleh, hasil respon (variabel terikat) yield biodiesel $28.55 \%$. Kondisi minimum didapat pada kondisi perbandingan mol 1:5.7 suhu $62^{\circ} \mathrm{C}$ dengan konversi yield $16.55 \%$.

\section{Daftar Pustaka}

Desy. C .D. 2015. Produksi Biodiesel Dari Minyak Jarak (Ricinus Communis) Dengan Microwave. Program Studi Teknik Kimia. Fakultas Teknik. Universitas Negeri Semarang.

Heyne.M. 1987. Biodiesel the Comprehensive Handbook. Australia 
Hidayat, J. (2012). Optimasi Pelilinan Dan Suhu Penyimpanan Buah IPB.

ManggisMenggunakan Response Surface Methodology (RSM). Bogor.

Jairurob, Ponsak, Chantaraporn Phalakornkule, Anamai Na-udom, Anurak Petiraksakul, "Reactive Extraction of After-Stripping Sterilized Palm Fruit to Biodiesel", Fuel 107, Hal: 282 - 289, 2013.

Knothe, G., Dunn, R. O., and Bagby, M. O., 1997, Biodiesel: The Use of Vegetable Oils and Their Derivatives as Alternative Diesel Fuels, Fuels and Chemicals from Biomass, ACS Symposium Series, V, 666.

Osava, M., 2001, The Castor-Oil Plant: Ricinus Communis Is The BestSource For Creating Biodiesel, Energyin Castor Bean, Tierramerica.

Pakpahan. 2001. Mengenal Biodiesel. Jakarta : UI Press.

Sudrajat,M. 2003. Biodiesel Alternatif Substitusi Solar Yang Menjanjikan Bagi Indonesia. Lembaran Publikasi Lemigas No 1/95. 